\title{
Decomposition of Epistemology and Decision- Making for the Era of Modern Management
}

\author{
Marko Perić*, Kristijan Krkač**, Hrvoje Volarević****
}

\begin{abstract}
Summary
In this paper, the authors describe the essential implications of epistemology for modern management theories in practical situations through the era of historical epistemology as postmodernism and neo-modernism by means of case studies (without individual detailed descriptions). The gender issue is mentioned in epistemology and its approach to change and strategy which renders the paper even more relevant. Moreover, scientific acknowledgement of practical stances, as also the moral paradigm, trigger discussion on applicable solutions in the corporate world for the intermediation of tangible and intangible goods and services. Three main areas of the business cycle are selected to represent three pillars of modern social-economic behaviour as our financial legacy in business and management transformation. In the last section of the paper are listed the reasons for narrowpicking, this being the first step in establishing a business model for a transformational strategy in the era of modern management.
\end{abstract}

Keywords: epistemology; change in strategy; scientific acknowledgements; moral paradigm; intermediation; transformational strategy; modern management

\section{Introduction}

The field of historical epistemology and philosophical epistemology of applicable situations and solutions are crucial for understanding the function of modern management as a contributing role model for a new generation of researchers, lecturers, managers and leaders. The authors offer an innovative way

* Marko Perić, MBA, Doctoral Candidate at Sheffield Hallam University and the Zagreb School of Economics and Management. Address: Howard Street, Sheffield S1 1WB, United Kingdom and Jordanovac 110, 10000 Zagreb, Croatia. E-mail: peric.markozg@gmail.com

* Kristijan Krkač, Ph.D., Professor. Zagreb School of Economics and Management. Address: Jordanovac 110, 10000 Zagreb, Croatia. E-mail: kristian.krkac@gmail.com

* Hrvoje Volarević, Ph.D., College Professor. Zagreb School of Economics and Management. Address: Jordanovac 110, 10000 Zagreb, Croatia. E-mail: hrvoje.volarevic@zsem.hr 
of conceptualising reflexivity as the exploration of a past state of mind in order to identify and understand management research in this distinctively philosophical enterprise regarding case study methods on regular classes or the business world. Neutral observation - from the standpoint of the authors - as reflective practice, is in the power of the underlying assumptions of philosophical epistemology, historical epistemology and epistemological alternatives. To endorse the reflexivity of the theoretical fundus, the authors have outlined the main issues which legitimise different management and leadership styles using epistemology, practical examples, theories, findings and conclusions relevant to the subject. Overall, limited sources dealing with the topic speak in favour of further research and the creating of incentives for students, professors and professionals in the industry.

Since this is a scholastic approach, it is extremely important to generate solutions from the aspect of the different genders and values as per the pluralism theory and also to identify — for the practitioner to understand - core values as capabilities and validation methods of the distinction between opinion and justified belief. These findings are interesting in regard to the studies of eminent authors such as Karl Popper, Thomas Kuhn, Paul Feyerabend and Imre Lakatos. Their focus is to prevail as alethic pluralism researchers rather than epistemological theorists. In essence, they help managers to understand "post-truth" thoughts about strategic roles and the roles of managers in the operational phase of a strategic change. Theoretical variety in the fundus also helps to improve past activities and research practice through case studies or to monitor behavioural impact, which can often represent reality with accuracy (Biglan, 1973). In management research, it is essential to rely on theoretical assumptions because the researcher is thus entirely focused on the introspective process (Steier, 1991) of the relationship between belief and mental outcome (Stroud, 2011). It helps in both ways - by developing a critical theoretical fundus and managing shortcuts for stressful situations. When a researcher is moving forward in the deductive procedure of the mid-period horizontal process, it is crucial, firstly, to understand the contradictions of backtesting and learning-by-doing testing of the theoretical system's internal consistency simultaneously. In light of these, as mentioned previously, the authors will proceed as follows:

In the first section, traditional epistemological conceptions will be confronted by more contemporary conceptions. Traditional conceptions rest on a tripartite analysis of knowledge plus or minus specific objections in terms of the reduction of some conditions (naturalised epistemology) or in terms of supplying additional conditions (as in contextualist, relevant alternatives and similar epistemologies), while contemporary conceptions view knowledge as an aspect of basic scientific procedure such as the modelling hypotheses, modelling testing, the experimental process and interpreting results as described and upheld by the classics of the second half of the $20^{\text {th }}$ century philosophers of science such as Popper, Kuhn, Feyerabend, Lakatos and others. This conception will 
be applied to management, especially to the decision-making process, which implies contemporary conceptions moreso than the traditional. (Namely, some general viewpoints will be described after establishing certain parallels between particular management decision-making models, actual case studies and epistemological implications. In conclusion to the first section, the authors suggest that a pluralistic, relativistic and hermeneutical epistemological background is more suitable for an understanding and justification of contemporary management practices, especially the decision-making process which can be viewed as a kind of know-how as opposed to traditional know-that. Here we cannot enter into contemporary discussions on the issue, but we should mention that our standpoint, in principle, rests on the traditional $20^{\text {th }}$ century pragmatist view according to Ryle.)

In the second section some elements from the first part in terms of contemporary conceptions that rest, as was said, on the basic ideas of the philosophy of science in the second half of the $20^{\text {th }}$ century, will be applied to particular elements of the managerial decision-making process as a type of know-how. The basic idea is to show, not the traditional concept of knowledge as the true justified belief, but rather the contemporary concept of knowledge as a rather pluralistic, interpretative and methodologically tolerant process of creating scientific models, applying them and finally restructuring them in view of the results of their application. This is the concept of knowledge that is implied, employed and of use in contemporary management, i.e. in the decision-making process in terms of its epistemological implications. (Metaphorically speaking, this could be labeled as the "anything goes" idea versus the "X method and only the X method is the right one.") Nowadays, also due to various contemporary business realities, a manager, especially during the decision-making process, needs to be aware of her/his own methodological, epistemological and other presuppositions in order not to make a series of mistakes that impact the real lives of human beings. Among these, epistemological implications, if not presuppositions, are quite important, given all the steps of the average decision-making process: steps such as, defining the problem, offering several solutions, choosing the best solution, applying and remodeling the solution, measuring the results of the application and making corrections and plans for future changes. Contemporary epistemological conceptions, as described by philosophies of science, are something that a contemporary manager needs to be aware of. Examples of such application and explication of the epistemological features of managerial know-how will be given subsequently in a separate text under Example 1, that is, from 1 to 7.

The basic idea of the present conceptual paper is to try to formulate a clear concept of knowledge that is implied in management, especially in the managerial decision-making process, and which needs to be explained not only by epistemologists and philosophers of science, but also by managers themselves, since their awareness of what they are doing (know-how) while reaching and applying far-reaching business decisions based on epistemological assumptions is 
of utmost importance in order for them to be able to identify their successes and failures. The basic result is the following: namely, the concept of knowledge used in management is essentially dual in nature. On the one hand, it is an extremely stringent reductionist concept of knowing-the-data (not false or fake data, but real data) and on the other hand, it is quite a tolerant, pluralistic, relative (not necessarily relativistic) and almost agnostic concept of knowledge in which everything possible is taken into account (even the unknown elements). As such, this concept of knowledge should be made clear at least in basic conceptual terms, not only concerning its philosophical background in the philosophy of science, but also in its actual application.

\section{The decomposition of epistemology principles and decision-making in the era of modern management}

\subsection{Management science thought as a method of the modern business world}

From the perspective of epistemology as the study of human behaviour, compatibility is crucial in distinguishing science from non-science. Frequently, however, epistemological knowledge is described as the perspective of conditions where warranted knowledge takes place (Johnson \& Duberely, 2000), while pragmatic realism as a critical realism has a place in the sociology of knowledge, foundationalism, emotional and cognitive psychology (Bernstein, 1983). The findings mentioned speak in favour of insights which occur concerning critical points in realism, called critical realism, which belongs to relativism or foundationalism. With the rapid rise of social and corporate culture, it is natural to have an external consciousness which predicts the aim of social scientific inquiry and the output thereof. This means predictions in improving social conditions by dealing with practical problems (Wong, 2012). In corporate governance and financial intermediation, this could be reflexive praxis in relation to the evaluation of pragmatic realism in terms of validation (the scientific approach), optimisation (the industrial approach) and cooperation.

As the study of nature moves away from the perception of knowledge, epistemology finds rationality in beliefs in four different areas: in the in-depth analysis of belief, justification and truth (Stanford Encyclopedia of Philosophy, 2014), in different approaches to the problem of skepticism, in the selection criteria for demanding validation of human knowledge and in its sources as the scope of justified beliefs (Frede, 1987). For this and many other reasons, the authors investigate a variety of different epistemological approaches and their effects and implications for management research in real situations or case studies. 
Table 1. Different approaches and their implication in epistemological studies with an example of a case study. Source: Johnson \& Duberely (2000) with modifications made by authors.

Tablica 1. Različiti pristupi i njihova implikacija u epistemološkim studijama s primjerom studije slučaja. Izvor: Johnson \& Duberely (2000) s izmjenama koje su napravili autori.

\begin{tabular}{|c|c|c|c|}
\hline $\begin{array}{c}\text { Conventional } \\
\text { Epistemic } \\
\text { Approach }\end{array}$ & $\begin{array}{c}\text { Reflexivity and its } \\
\text { approach }\end{array}$ & Focus & Facebook \\
\hline Postmodernism & $\begin{array}{c}\text { The impossibility } \\
\text { of reflexivity }\end{array}$ & Conservativism & Alibaba \\
\hline $\begin{array}{c}\text { Neo- } \\
\text { postmodernism }\end{array}$ & $\begin{array}{c}\text { Hyper-reflexivity } \\
\text { and futurism }\end{array}$ & $\begin{array}{c}\text { The reflexive approach } \\
\text { toward decomposition } \\
\text { of one's practice }\end{array}$ & Coca Cola \\
\hline Neo-positivism & Methodology & $\begin{array}{c}\text { Improving methods and } \\
\text { implications }\end{array}$ & Berkshire \\
\hline Critical realism & $\begin{array}{c}\text { Epistemic } \\
\text { reflexivity }\end{array}$ & $\begin{array}{c}\text { Approving emancipation } \\
\text { through realism }\end{array}$ & Hathaway \\
\hline
\end{tabular}

For instance, when we move to more applicable situations, sense-perception is something that operates only under controlled and correlated conditions for breaking life-long barriers. From this standpoint, in Table 1, positivists explain human behaviour in an organisation when an a priori external reality is imposed upon human behaviour to explain it. In contrast, neo-positivists purport that researchers should analyse human behaviour in an organisation from an a posteriori understanding. Conversely, it can be merely an isolated sample in the population during a case study session on classes. According to this pattern, the study of human knowledge is like studying the concept of human life, particularly case studies with implications in the financial industry. Socialisation, digestion and respiration could have all of this through case studies in modern management.

Example 1. For example, during a management session, it is not recommended to scan applicable and available literature in financial or management studies. It is crucial to understand the rule of the financial background on supply and demand in economic models and corporate governance. In terms of the transaction cost economics (TCE) and agency theory, the limitations which exist in unemployed human capital speak in favour of criticism in the quantitative sphere. Logically, the reason for this could lie in the rapid growth of multidimensional performance regarding corporate governance, human leadership, artificial intelligence and ethics.

The structure of scientific revolution is extremely important in view of crisis management as one of the biggest issues in the 21st century. The same goes for management - a journey to a "worthwhile leadership". From a practical standpoint in total quality management (TQM) and in keeping with fads, a straightfor- 
ward world with limited utility sources keeps all in a ceteris paribus state. ${ }^{1}$ We can be sure that radical change in the direction of both poles (objective and subjective) can have the same boomerang effect regarding steady change. In specific role management and typology there are four types of mindsets of strategic and turnaround managers and leaders: the analytic thinker (changes can be managed in an orderly and progressive manner), the effective manager (supports incremental change), the change master (seeker for practical and sophisticated action) and reflective leader (creates positive vibes at the same time as giving critiques).

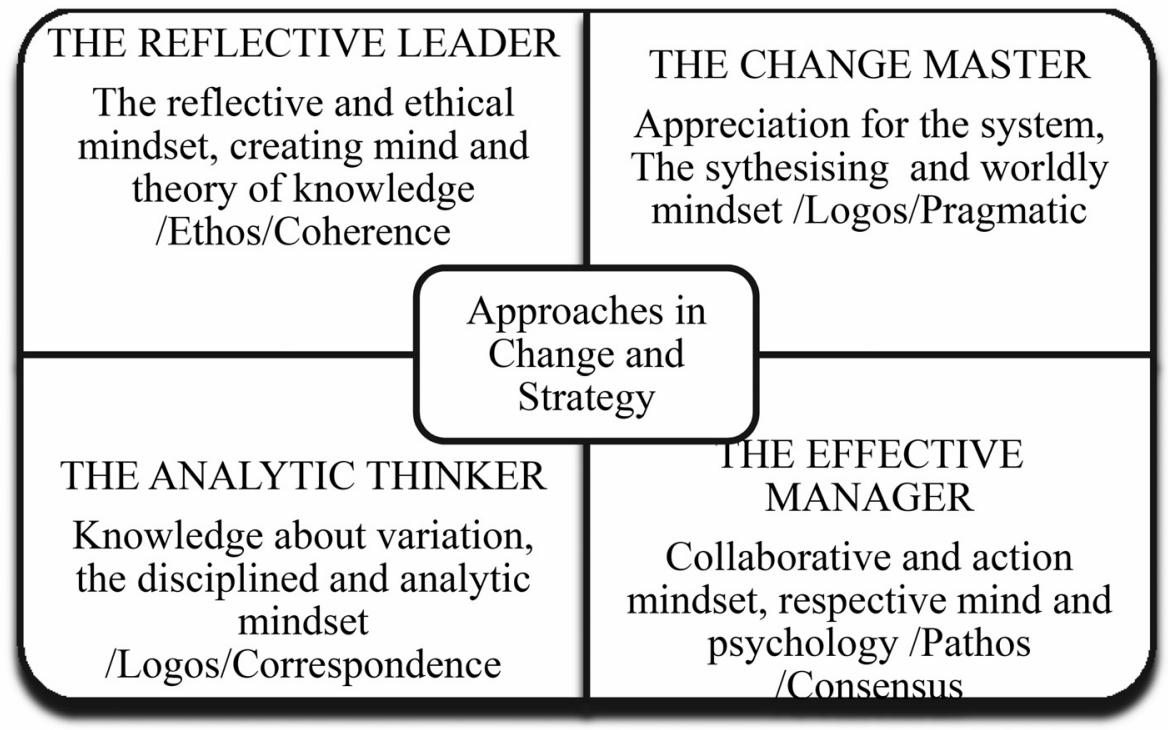

Image 1. Approaches in Change and Strategy. Source: Darwin (2004).

Preventing Premature Agreement. Philosophy of Management, 4(1), 41-54.

Slika 1. Pristupi u promjenama i strategiji. Izvor: Darwin (2004). Preventing

Premature Agreement. Philosophy of Management, 4(1), 41-54.

Moving back to our original thought, the assessment and application of epistemology in the era of modern management could become a condition of knowledge. What does this mean?

Example 2. This means that derivation of such practical knowledge (knowhow) cannot be completely applicable in real-life situations. Moreover, the relationship between the researcher and the object is seen in the introspective process of different types of epistemology. Some of these will be explained subsequently.

1 Hyde (1992) and Cohen and Brand (1993) had confirmed that management must be heavily involved as leaders rather than followers from the perspective of separate staff members in the process of making crucial decisions as shepherding the effort. 


\subsubsection{Virtue epistemology (careful and attentive reasoning) — always seeking the "profound" rather than what is "right"}

It is more accurate to investigate than to explore with a known pattern, also known as cognitive abilities regarding competencies (Sosa, 2007) and virtue responsibilism as well as virtue reliabilism as meeting requirements for cognitive performance on their own. From the perspective of researchers, it is essential to understand the motions and emotions of the "genesis of knowledge" as "virtues of the mind" regarding the definition of the "conceptual analysis of knowledge" (Baehr, 2008). From the concept of naturalistic epistemology, all of the above can be conveyed as "understanding priorities" and "order, not rule by law". Moreover, significant impact thereupon is seen in the inter-connection between praxis and academia in terms of doing by making errors.

\subsubsection{Naturalised epistemology (cognitive psychology replacing the traditional with the redefined process) - in the matrix world, it is more common to do something by making errors or using a tailor-made concept than in the traditionalist manner as regards normative postulates and behaviour}

The above-mentioned is frequently known as the process of knowledge acquisition with a focus on empirical tradition and cognitive science. David Hume is a representer of replacement naturalism which describes scientific knowledge as the "aid of less certain set-theoretic notions". He says that the situation of the non-cooperative relationship between scientific knowledge and logical structures is impossible for an "understanding of scientific knowledge" (Quine, 2004). The four roles already mentioned in this paper - namely, the analytic thinker, the effective manager, the change master and the reflective leader - are the starting point for "screening criteria" in moral epistemology.

\subsubsection{Moral epistemology (the distinction between "right" and "wrong" and doing it "right" and "wrong") - moral behaviour in the business world is the construction of the will to surf the corporate ladder without asking the "wrong” questions}

We have taken into consideration two opposite meanings of certain interesting facts as presented to us by positivists and subjectivists (Baum, 2014). The term "normative morality" is a pattern of perpetual improvement of actual behaviour concerning the value of fairness such as "deontic logic" and the "ultimatum game" in which the opposite side responds as the well-known "war chess game". Simon (1967) has pointed out there is no place for the "ethical assertions of science" in our world, but ironically, there is sympathy for at least one form of objective value. The interpretation of his work regarding the acumen of business schools (Khurana, 2012; Spender, 2012) as the perspective of business capital in the "intellectual context" is the openness of diversity regarding normative, social and ethical theories and commitments towards pure positive explanations, normative prescription and intrinsic moral values. In following the actions of people, 
we see that they cheat more when others can benefit from the standpoint of cheating, while the number of beneficiaries of the wrongdoing progressively increases (Gino, 2013). For this reason, researchers often incorporate these findings into the objective activity of moral research as part of social epistemology.

\subsubsection{Social epistemology (the objective of the rationality of norms corresponding with traditional norms) - construction of social categories regarding education is often opposed to financial status and background}

From the perspective of a researcher, it is difficult to underestimate the potential for pluralism without a foothold in the justification of "testimony on an epistemic sense of feeling, memory and perception" (Lackey, 2011). According to Fuller (2006), unusual interpretations have a significant impact on the connotation of unrealised gains regarding belief and paradigm inherent in human behaviour, relationship and business performance essential for achieving personal and professional aims.

Example 3. This particular point is necessary when the subject does not take into consideration the moral hazard in economics, corporate governance and applicable legislation. The other scientific approach works in favour of the odds of feminist epistemology and the capability absorption mechanism as a timeline for better decision-making in crucial situations and viable management styles as in feminist epistemology.

\subsubsection{Feminist epistemology (oppression of women in particular cases, which is suitable for the understanding of human nature) — gender equality regarding leadership is more relevant than ever before}

All these are instances of what has been described as "the politics of knowledge-ignorance" (Schumann, 2016; Tuana, 2004). ${ }^{2}$

Example 4. The report on 87 studies involving tests for the quality of transformational leadership (styles and measures of leader effectiveness) speaks in favour of female leadership which is associated with greater effectiveness (Eagly, 2007) than in the case of males. Women tend to be more visionary when team tasks are characterised, such as high regard for people in UK studies (Cartwright, 1995; Gale, 1995). Additional studies reported by the Calipier Organization (2014) acknowledged the transformational style of leadership by women as more intellectually stimulating and as providing inspirational motivation. Pervasive stereotypes exist regarding gender abilities and prejudice known as "glass ceiling" which sets limits for those rising in the corporate world (Eagly, 2012). The reason for this appears to be the enhancing of internal efficiency ratios and indicators against self-oriented management styles (learning-by-not-doing). The next chapter will coordinate the findings with the moral paradigm. 


\subsection{Moral paradigm}

Inapplicable situations could be procedures which have their source in our feelings, thoughts and practical experience. The most intuitive is opposed to prior knowledge. As regards epistemology, scientists use values which are understandable to the broader public, that is, subjective theory as part of the "moral hermeneutic paradigm" regarding implications in the real-world: a) autonomy as understanding the world in our own terms in the way that logic and rationalities function (representing roots of logic which is not pure "logos"); b) meaningful coherence - understanding events more holistically; seeing oneself as a complete person (adopted from Bleicher, 1982 - Hermeneutic Imagination); c) preunderstanding - as training which puts us into doubtful situations (predefined criteria as a controlled experiment, as the non-incentive procedure of finding the right situation for main and sub-roles); d) meaning equivalence - capturing who we are?! (subjectiveness as a personal dimension in human behaviour) — often meaning the right to have an opinion, which, on the other hand, is not an opinion, but rather just a fact taken from "leaflets".

Justification of knowledge occurs in stages and has a variety of causes. The most significant are introspection, reason, memory, perception and testimony. Perception often reflects a mirror image of reality described as perceptual seemings which has to do with direct and indirect realism. On the basis of the above, we can conclude that most of us have a deep capacity to rethink the current situation and a variety of solutions for the future. Inside of us is the capacity to absorb perceptual experiences. This is called introspection with less error progress. It can be an "infallible faculty", while on the other hand there is a practical sense of knowing, that is, a practical sense of "learning-by-doing", known as memory - experience by means of knowing-by-doing. The core value of our knowledge is the functional acquisition of moral versus immoral competing values, which is, for management and intermediatory financial industry, of utmost importance in regard to CSR (Corporate Social Responsibility).

\section{Discussion on applicable solutions in the corporate world}

According to the Financial Times (2015), most people correlate with different variables regarding specific preferences: "I'm not a moral philosopher, I'm a social scientist [...] So I'm going to teach you social science, and hopefully somewhere along the line, in religion or your parents or your peers or something you've read, you've learned how to use the power that you're going to get for good rather than evil" (Hill et al., 2015, 5-6).

From this standpoint, moral objectivity as a device could help readers to understand how to achieve their maximum while using familiar shortcuts for everyday purposes in relevant or irrelevant practical stances or situations. 


\subsection{The background of knowledge as being relevant or irrelevant for practical situations}

A relevant question concerning this statement should perceive time and place as a relevant factor. Humans perceive things themselves by gradually socialising into a culture which "feeds" them. Is there such a thing as a guilty situation if no one perceives anything even in the immediate future? Is there anyone who knows about the thoughts and feelings of others? Is there any possibility for truth not to be truth alongside a necessary truth or standards? Objective hermeneutics is uderstood as a data concept of objectivity in qualitative form (data mining toward social interaction). It could be a valid concept of pointing out the authenticity of those mentioned above - known solutions. Moreover, it is difficult to manage and define relevant and irrelevant situations, while the mission and vision of the individual are not moving toward human expectations. This will be discussed in the next chapter.

\subsection{The easiest way to acquire deeper knowledge and techniques of intermediation (investigating human knowledge in the manner of learning by pursuing it)}

People try always to know as many things as possible. It is normal to find a solution to what is right at a given moment. Sometimes they assert this without considering or rejecting the hypothesis and other necessary factors - thoughts and feelings of other people. Any knowledge which challenges obstacles is a type of solution for more shrewd persons. As for acquiring cultural awareness, a skeptical hypothesis could go from failure to failure without knowing what is wrong. No, this is just a learning technique on how to deal with everyday issues. Management cooperation as coordination between corporate functions places many critics into viable economic models and corporate governance and its interpretations through professional audits. Example 5. In pointing out the already mentioned term TCE (Total Cost Economics) we oversimplify agency theories which are important for decision-making and for predicting excessive emphasis on self-interest mechanisms such as incentives and theories of organisational economics (Dalton et al., 1999, 2003; Westphal, 1999; Zajac and Westphal, 1994). ${ }^{3}$ They speak in favour of management decision concerning applicable hints, models, simulations and added value theories which are of value in our further investigation and the findings mentioned in the next chapter.

\subsection{The basis for creating justified beliefs and a proposition for important private or business cases}

As in the relationship between private and business cases, there exists the same bridge between philosophical epistemology and the history of epistemology.

3 Van Ees, H.; Gabrielsson, J.; Huse, M. (2009). Toward a behavioral theory of boards and corporate governance. Corporate Governance: An International Review, 17(3), 307-319. 
Both endeavour to answer the question of the possibility of obtaining knowledge in the world using storytelling hints in the modern theory of neo-positivism. They do not acknowledge this (history of epistemology) because their view entails the concept of perception of alternatives and knowledge about the world (traditional epistemology). In essence, human knowledge is interpreted as digestion or human socialisation or human respiration with modifications through the ages taking on its unique form of a kind of philosophical investigation (without agreement in advance by abstract argument), and this is the legacy of epistemological conceptions mainly that of Popper, Kuhn and Feyerabend.

Moreover, the difference between human language, specific uncorrelated programming language and socialisation can be part of the positivism and neopositivism theory, which is unusual for the era of modern management leadership and corporate governance. Thinking more about the preceding statement in the personal dimension according to moral interference in postulates of positivism and neo-positivism as a subject of dualism, it extracts conclusions from the roots of cultural experiences. Most people say it is crucial to follow patterns of moral behaviour, devoted cum granis salis in the manner of a mature leader. Frankly, it can be bypassed by subjectivists as a matter — by its very nature — which is in the blood of the ontologist and a position taken for an "understanding the social world from time to time". This conclusion follows from the fact that a particular situation can reflect a model or decision-making situation through the example of interpretation of international accounting standards in the financial industry. Situations such as this are crucial for vigorous decisions and an understanding of how epistemology works as one possible approach in the transformational management theory.

Example 6. Firstly, the management team and consultants should ask themselves two questions - Which things can be tampered with? What is needed to win? The answer should be - bills need to be paid fast, while customers are extremely important to us. More generally, these basic findings are consistent with research showing how difficult it is to determine the min-max value of assets on the market. For this reason, in the world of finance, it should be a form of the weighted cost of acquisition for the buyer which covers three main areas of the business cycle: a) Expansion of scope - revenue focus of a cross-selling of new products to existing customers and vertical integration of the process; $b$ ) Expansion of scale - optimising short-term costs (OPEX) for better long-term performance (CAPEX) as a role of the cost centre; c) Expansion of capabilities - the role of defending risky opportunities to narrow shareholder value.

It depends on everything: on construction, on reality or partial construction regarding justified beliefs as common sense (practical interest sociology (DeRose, 2002; J. Fantl \& McGrath, 2011; Stanley, 2005)). For the relevance of our research work and the application of the topic of interest, the pertinent questions should be: a) What motivates people not to replicate existing financial or business models in case studies? b) What do you want to become tomorrow - a leader or a follower? c) How do you deal with issues in the financial industry? d) How 
do you understand all topics regarding your subjective manners and preferences?

e) How do you measure return on investment and change in today's world?

These issues are important in the field of research and are a contribution to professional and business knowledge in case study models for the propulsive field of finance, accounting and management. Over recent years, we have seen that much can be accomplished in raising overall standards and the well-being of humanity.

Example 7. Many types of research deal with the issue of equality in collaboration with stakeholders. However, as regards financial standards, the key concern in coexistence could be benefits from financial intermediation and cost structure depending on the substantial construction of reality regarding asymmetric information and the principal-agent problem (Kaplan, 2005; Schoar, 2005; Lopez-de-Silanes, 2005; Phalippou, 2013; Gotschlg, 2013). ${ }^{4}$ The aggressive and insubordinate features undertake social science and the development of organisation theories as a "cascade walk" towards the corporate ladder concept. It is not what many people talk about or see via normative stances and the historical impact in epistemology. "Narrow-picking" in terms of ethical decision-making in the essentials of the economy, can be an unforgettable gift for future generations of leaders for the following reasons: a) The gap in supply and demand; b) Aggregation of raw materials in the economy; c) Planning the process of optimisation; d) Capital budgeting of investments; e) Intermediation with intangible services.

From the perspective mentioned above, it is crucial to establish a business model with all relevant factors to control risk and appropriate behaviour with professionals from a particular field of interest. Moreover, supranational institutions certainly would not take a mitigation risk when systematic risk is at the pole position. Thus, all the aforementioned is something which will transform not just management style leadership, but the way of approaching peer-to-peer relationships in daily situations.

\section{Conclusion}

To sum up, avoiding any conflict of interest or stipulating "laissez-les faire" leadership is the result of getting out of one's comfort zone as in the context of moral epistemology and the traditional tripartite analysis of knowledge. Knowledge is defined and used as an aspect of scientific process with all its shortcomings, failures and improvements and not as a conservative concept which is practically inapplicable to contemporary managerial practices which govern our daily lives and which need to be epistemologically sound as much as is humanly possible, meaning that a decision-maker should be aware of what she/he is doing while making and applying managerial decisions. Traditionally irrational elements of 
knowledge such as social and cultural contexts, motivation, emotions and purely practical know-how should be included here. This is the basic idea of the paper and is substantiated in the first and the second sections thereof.

Also, the practical standpoint of epistemology should be mentioned. It is easy to conclude that the said perspectives and views could help us find a way in which to deal with everyday issues regarding private, moral and professional attitudes. From the intellectual context and methodological openness, the terminology works in favour of the more traditional context (empiricism and objectivism) against fundamental and "from the book" examples. Due to the complexity of ethics and science, it is crucial to find the best way of applying the moral paradigm for personal and professional use.

Different ethical genders were put in an unconventional ethical context and thus became closer to and more familiar with real situations. Also, from contemporary viewpoints, the findings above are specific topics regarding cultural awareness, social context and social-psychological implications of epistemology upon real cases and solutions. Acquisition of the three pillar model representing the three main areas of the business cycle gives the reader enough time to analyse thoughts, feelings, findings such as a leader, not a manager, would do. Last but not least, it is the view of the authors that the terminology used in this paper is a good starting point for expanding one's vocabulary when combined with different approaches from different backgrounds.

In terms of future research, since this is a conceptual paper that attempts to formulate a clear concept of knowledge which is essential for management sciences and practice, certain elements should be researched in more detail.

\section{Bibliography:}

Abraham, William James (2006). Crossing the Threshold of Divine Revelation. Grand Rapids, Michigan: Eerdmans Pub Co.

Alston, William Payne (1976). Two Types of Foundationalism. The Journal of Philosophy, 73(7), 165-185.

Alvesson, Mats; Willmott, Hugh (2012). Making Sense of Management: A Critical Introduction. London: Sage Publications.

Astley, W. Graham; Zammuto, Raymond F. (1992). Organization Science, Managers, and Language Games. Organization Science, 3(4), 443-460.

Baillie, James; Meckler, Mark R. (2012). Truth and Objectivity Regained. Journal of Management Inquiry, 21(3), 248-260.

Biglan, Anthony (1973). Relationships Between Subject Matter Characteristics and the Structure and Output of University Departments. Journal of Applied Psychology, 57(3), 204.

Bourdieu, Pierre (1990). The Logic of Practice. Stanford: Stanford University Press.

Breyer, Daniel; Greco, John (2008). Cognitive Integration and the Ownership of Belief: Response to Bernecker. Philosophy and Phenomenological Research, 76(1), 173-184.

Brink, David (1989). Moral Realism and the Foundations of Ethics. Cambridge: Cambridge University Press. 
Cartwright, Nancy; Hardie, Jeremy (2012). Evidence-Based Policy: A Practical Guide to Doing It Better. Oxford: Oxford University Press.

Chia, Robert (1995). From Modern to Postmodern Organizational Analysis. Organization Studies, 16(4), 579-604.

Donaldson, Thomas; Walsh, James P. (2015). Toward a Theory of Business. Research in Organizational Behavior, 35, 181-207.

Eagly, Alice H. (2007). Female Leadership Advantage and Disadvantage: Resolving the Contradictions. Psychology of Women Quarterly, 31(1), 1-12.

Evans, Maggi (2013). Women in Leadership-A Different Story. Psychologist, 26(12), 874-876.

Frede, M. (1987). Observations on Perception in Plato's Later Dialogues. U: M. Frede (ur.), Essays in Ancient Philosophy (str. 3-10). Minneapolis: University of Minnesota Press.

Gergen, Kenneth; Gergen, Mary (1991). Toward Reflexive Methodologies. U: Frederick Steier (ur.), Research and Reflexivity (str. 76-96). London: Sage Publications.

Ghoshal, Sumantra (2005). Bad Management Theories are Destroying Good Management Practices. Academy of Management Learning \& Education, 4(1), 75-91.

Gino, Francesca; Ariely, Dan (2012). The Dark Side of Creativity: Original Thinkers Can Be More Dishonest. Journal of Personality and Social Psychology, 102(3), 445.

Greenberg, Mark (2011). Naturalism in Epistemology and the Philosophy of Law. Law and Philosophy, 30(4), 419.

Holland, Ray (1999). Reflexivity. Human Relations, 52(4), 463-484.

Jensen, Michael C.; Meckling, William H. (1976). Theory of the Firm: Managerial Behavior, Agency Costs and Ownership Structure. Journal of Financial Economics, 3(4), 305-360.

Johnson, Phil; Duberley, Joanne (2003). Reflexivity in Management Research. Journal of Management Studies, 40(5), 1279-1303.

Kim, Tae Wan; Donaldson, Thomas (2018). Rethinking Right: Moral Epistemology in Management Research. Journal of Business Ethics, 148(1), 5-20.

Kuhn, Thomas S. (1970). Reflections on my Critics. Criticism and the Growth of Knowledge, 4, 231.

McGrath, Sarah (2010). Moral Realism without Convergence. Philosophical Topics, 38(2), 59-90.

Parker, Martin (1992). Post-Modern Organizations or Postmodern Organization Theory? Organization Studies, 13(1), 1-17.

Quine, Willard Van Oman (2004). Quintessence: Basic Readings from the Philosophy of WV Quine. Cambridge, Ma: Harvard University Press.

Sison, Alejo G. (2015). Happiness and Virtue Ethics in Business. Cambridge: Cambridge University Press.

Sosa, Ernest (1991). Knowledge in Perspective: Selected Essays in Epistemology. Cambridge: Cambridge University Press.

Steup, Matthias; Turri, John; Sosa, Ernest (ur.) (2013). Contemporary Debates in Epistemology. Chicester, West Sussesx: John Wiley \& Sons.

Van Ees, Hans; Gabrielsson, Jonas; Huse, Morten (2009). Toward a Behavioral Theory of Boards and Corporate Governance. Corporate Governance: An International Review, 17(3), 307-319.

Watson, Tony J. (1995). Rhetoric, Discourse and Argument in Organizational Sense Making: A Reflexive Tale. Organization Studies, 16(5), 805-821. 
Wong, James; Chan, Albert; Chiang, Y. H. (2012). A Critical Review of Forecasting Models to Predict Manpower Demand. Construction Economics and Building, 4(2), 43-56.

Yin, Robert K. (1994). Discovering the Future of the Case Study: Method in Evaluation Research. Evaluation Practice, 15(3), 283-290.

Dekompozicija epistemologije i donošenja odluka u doba modernoga upravljanja Marko Perić*, Kristijan Krkač**, Hrvoje Volarević***

\section{Sažetak}

Uovom radu autori opisuju bitne implikacije epistemologije u praktičnim situacijama kroz doba povijesne epistemologije prema modernim teorijama menadžmenta kao što su postmodernizam i neomodernizam kroz primjer studija slučaja (ne opisujući ih pojedinačno u detalje). Spol se spominje u epistemologiji i njezinu pristupu promjenama $i$ strategiji koja čini rad još relevantnijim. Štoviše, znanstvena priznanja prema praktičnim stavovima u isto vrijeme kao i moralna paradigma okidač su za raspravu o primjenjivim rješenjima u korporativnom svijetu u ulozi posredovanja materijalnih i nematerijalnih dobara i usluga u dijelu rasprave. Tri glavna područja poslovnoga ciklusa izdvojena su kao tri stupa modernoga društveno-ekonomskoga ponašanja kao financijsko nasljeđe u poslovnoj i upravljačkoj transformaciji. Uzadnjem dijelu rada, razlozi za suženo biranje prvi su korak uspostavljanja poslovnoga modela kao transformacijska strategija u doba modernoga menadžmenta.

Ključne riječi: epistemologija; promjena u strategiji; znanstvena priznanja; moralna paradigma; posredovanje; transformacijska strategija; moderno upravljanje.

* Marko Perić, MBA, doktorant, Sheffield Hallam University i Zagrebačka škola ekonomije i menagementa. Adresa: Howard Street, Sheffield S1 1WB, Ujedinjeno Kraljevstvo; Jordanovac 110, 10000 Zagreb, Hrvatska. E-adresa:peric.markozg@gmail.com

** Prof. dr. sc. Kristijan Krkač, Zagrebačka škola ekonomije i menagementa. Adresa: Jordanovac 110, 10000 Zagreb, Hrvatska. E-adresa: kristian.krkac@gmail.com

*** Dr. sc. Hrvoje Volarević, prof. v. š., Zagrebačka škola ekonomije i menagementa. Adresa: Jordanovac 110, 10000 Zagreb, Hrvatska. E-adresa: hrvoje.volarevic@zsem.hr 